\title{
₹USGS
}

science for a changing world

\section{Stability of Leaning Column at Devils Tower National Monument, Wyoming}

By Edwin L. Harp and Charles R. Lindsay

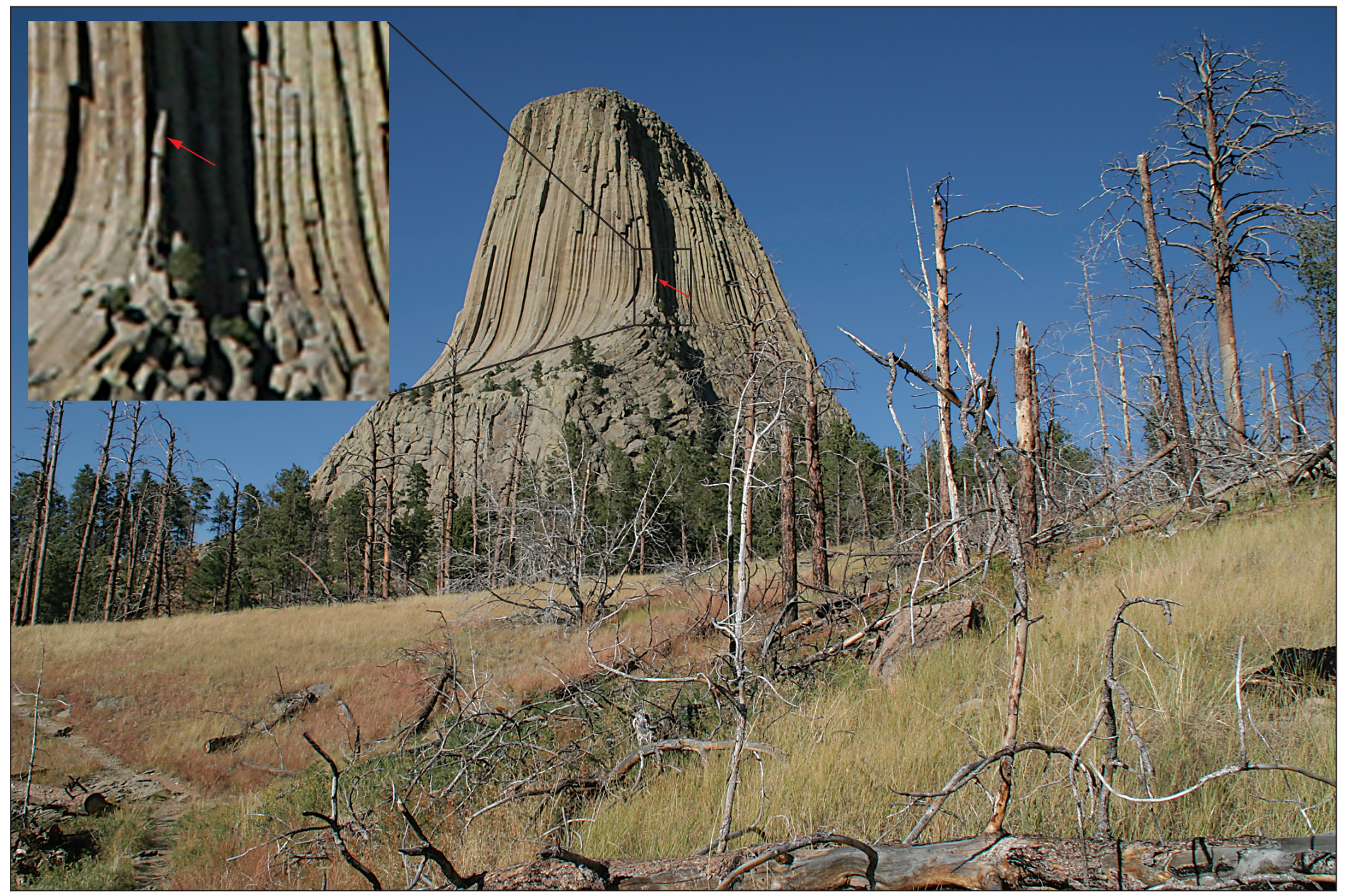

U.S. Geological Survey Open-File Report 2006-1130 


\section{U.S. Department of the Interior \\ DIRK KEMPTHORNE, Secretary}

\section{U.S. Geological Survey \\ P. Patrick Leahy, Acting Director}

U.S. Geological Survey, Reston, Virginia 2006

For product and ordering information:

World Wide Web: http://www.usgs.gov/pubprod

Telephone: 1-888-ASK-USGS

For more information on the USGS - the Federal source for science about the Earth, its natural and living resources, natural hazards, and the environment:

World Wide Web: http://www.usgs.gov

Telephone: 1-888-ASK-USGS

Harp, Edwin L., and Lindsay, Charles R., 2006, Stability of Leaning Column at Devils Tower National Monument, Wyoming: U.S. Geological Survey Open-file Report 2006-1130, 10 p.

Any use of trade, firm, or product names is for descriptive purposes only and does not imply endorsement by the U.S. Government.

Although this report is in the public domain, permission must be secured from the individual copyright owners to reproduce any copyrighted material contained within this report.

Cover photograph: Devils Tower with leaning column visible (red arrow) at lower left edge of vertical shadow on tower face. 


\section{Contents}

Abstract ton

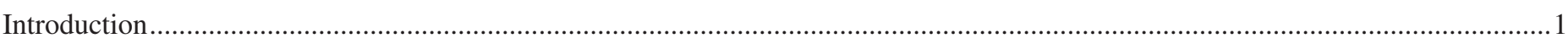

Geologic and Topographic Setting of Devils Tower

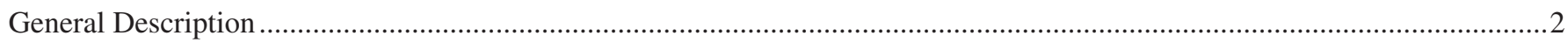

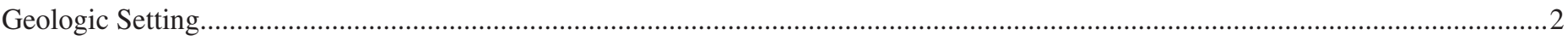

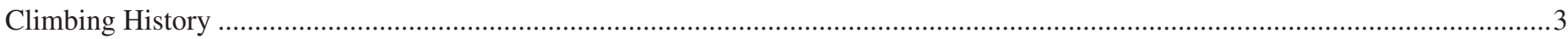

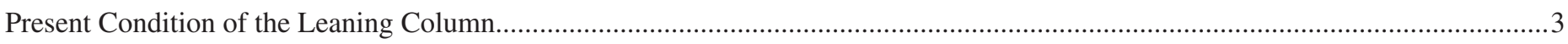

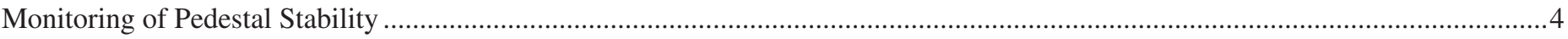

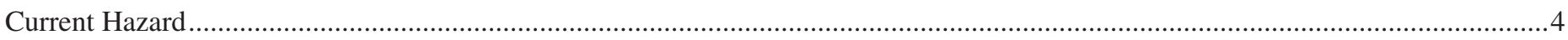

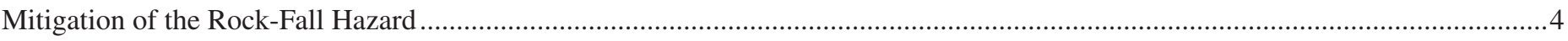

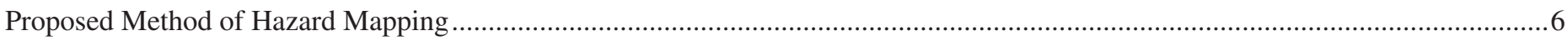

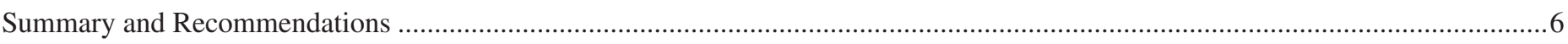

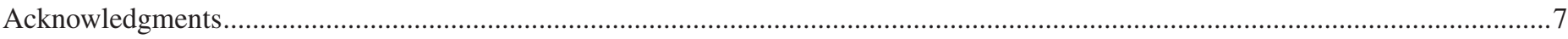

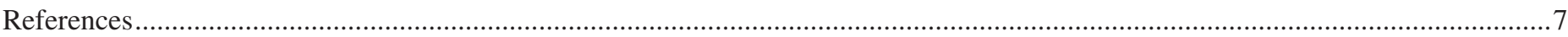

\section{Figures}

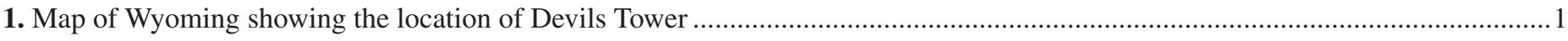

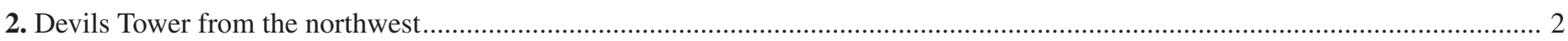

3. Telephoto of the leaning column showing the three segments, the underlying pedestal, and the upper point contact with an adjacent in-place column

4. (A) Schematic drawing of leaning column indicating viewing orientations of figures 5, 6A, and 6B. (B) Leaning column from below the climber standing on top of the column. Line of arrows indicates lower part of Durrance route

5. Leaning column resting on underlying pedestal in line contact. Black arrow points to area of fresh phonolite where spalling failure has occurred. Also note hairline fractures (red arrows) extending down from line contact with overlying column

6. (A) Upper corner of leaning column showing point contact (arrow) with adjacent column, and (B) Point contact of leaning column with adjacent column from above.....

7. View of line contact of leaning column with underlying pedestal showing freshly painted surface, which will allow any further spalling failures to be detected. 


\title{
Stability of Leaning Column at Devils Tower National Monument, Wyoming
}

\author{
By Edwin L. Harp and Charles R. Lindsay
}

\section{ABSTRACT}

In response to reports from climbers that an 8-meter section (referred to as the leaning column) of the most popular climbing route on Devils Tower in northeastern Wyoming is now moving when being climbed, scientists from the U.S. Geological Survey inspected the site to determine the stability of the column and the underlying column that serves as a support pedestal. Evidence of a recent tensile spalling failure was observed on the pedestal surface immediately beneath the contact with the overlying leaning column. The spalling of a flake-shaped piece of the pedestal, probably due to the high stress concentration exerted by the weight of the leaning column along a linear contact with the pedestal, is likely causing the present movement of the leaning column. Although it is unlikely that climbers will dislodge the leaning column by their weight alone, the possibility exists that additional spalling failures may occur from the pedestal surface and further reduce the stability of the leaning column and result in its toppling. To facilitate detection of further spalling failures from the pedestal, its surface has been coated with a layer of paint. Any new failures from the pedestal could result in the leaning column toppling onto the climbing route or onto the section of the tower trail below.

\section{INTRODUCTION}

In June 2005, climbers who frequently scaled one of the main climbing routes to the summit of Devils Tower began reporting that a leaning rock column that lies along the route and is typically

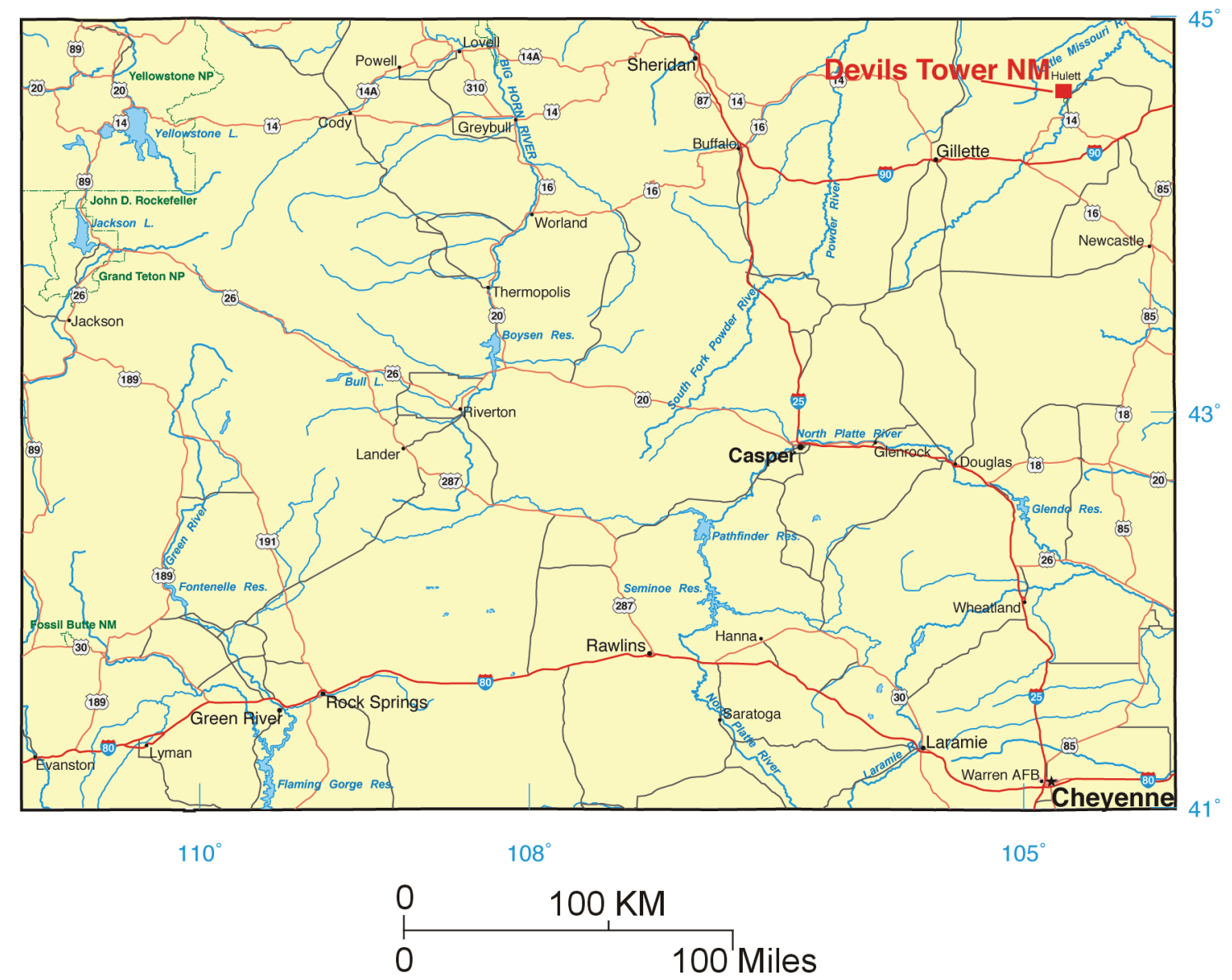

Figure 1. Map of Wyoming showing the location of Devils Tower. climbed as part of the ascent was moving. The 8-meter-long column, which has apparently been in a stable attitude leaning back against an adjoining column of the tower throughout historical time, appeared to be rigid despite its reclining nature until June 2005. Upon receiving confirmation from National Park Service (NPS) climbing rangers that the column indeed was moving under the weight of climbers, the Chief Ranger's office at Devils Tower National Monument contacted the U.S. Geological Survey to request that Survey scientists visit and evaluate the present stability of the column. Subsequently, a scientist from the Central Region Geologic Hazards Team, National Landslide Hazards Program, and a scientist from the Central Region Crustal Imaging and Characterization Team traveled to Devils Tower to inspect the column. 


\section{GEOLOGIC AND TOPOGRAPHIC SETTING OF DEVILS TOWER}

\section{General Description}

Devils Tower is one of the best known landmarks of the

Black Hills region (fig. 1). It is a steep-sided igneous body that exhibits spectacular columnar jointing, looming $386 \mathrm{~m}$ above the Belle Fourche River in northeastern Wyoming. President Theodore Roosevelt established Devils Tower and a small surrounding area as the first National Monument in 1906.

\section{GEOLOGIC SETTING}

The geology of the Black Hills and Devils Tower is described in several classic publications (Newton and Jenney, 1880; Jagger, 1901; Darton and O'Harra, 1907). Devils Tower is one of several igneous intrusions that were emplaced in the northern Black Hills during the Paleocene to Eocene epochs. Recent ${ }^{40} \mathrm{Ar} /{ }^{39} \mathrm{Ar}$ geochronologic data indicate that the tower was emplaced at $49 \mathrm{Ma}$ (Duke and others, 2002). Devils Tower intrudes Mesozoic sedimentary rocks of the Spearfish, Gypsum Spring, and Sundance Formations. Erosion and exhumation of Devils Tower occurred in the late Cenozoic (less than $10 \mathrm{Ma}$ ) and was likely most active during the last 3 million years (Small and Anderson, 1998; Zaprowski and others, 2001).

Devils Tower consists of columnar jointed phonolite. The rock is porphyritic with phenocrysts of anorthoclase, aegirine-augite, and sphene in an olive gray aphanitic groundmass (Halvorsen, 1980). The tower rises almost $250 \mathrm{~m}$ above the sedimentary rocks that it intrudes and is surrounded by talus. The upper $190 \mathrm{~m}$ is characterized by exceptionally well developed columnar joints that slope $75^{\circ}$ to $80^{\circ}$ from horizontal (fig. 2). These columns taper from 2 to $3 \mathrm{~m}$ in diameter at the base to $1.5 \mathrm{~m}$ in diameter at the top. The lower $60 \mathrm{~m}$ of the tower is defined by outward-flaring columns that become massive in structure with increasing distance from the upper section (fig. 2). Most columns are hexagonal, although some are 4- or 5-sided. Columns sometimes merge or split. The top $50 \mathrm{~m}$ of the tower exhibits significant horizontal jointing and is more weathered than the lower section. Devils Tower is completely surrounded by a broad apron of phonolite talus. Halvorsen (1980) identified at least four ages of talus based on development of soil horizons.

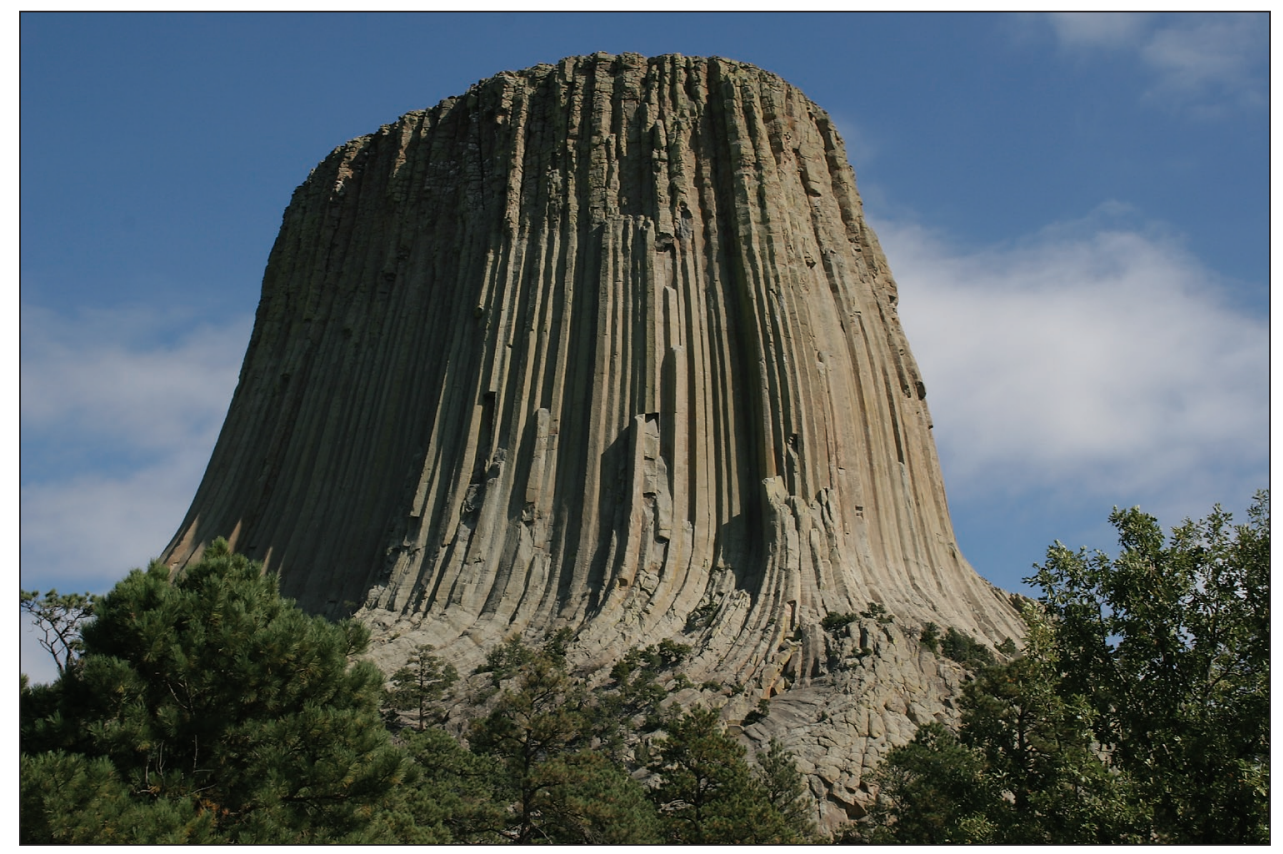

Figure 2. Devils Tower from the northwest.

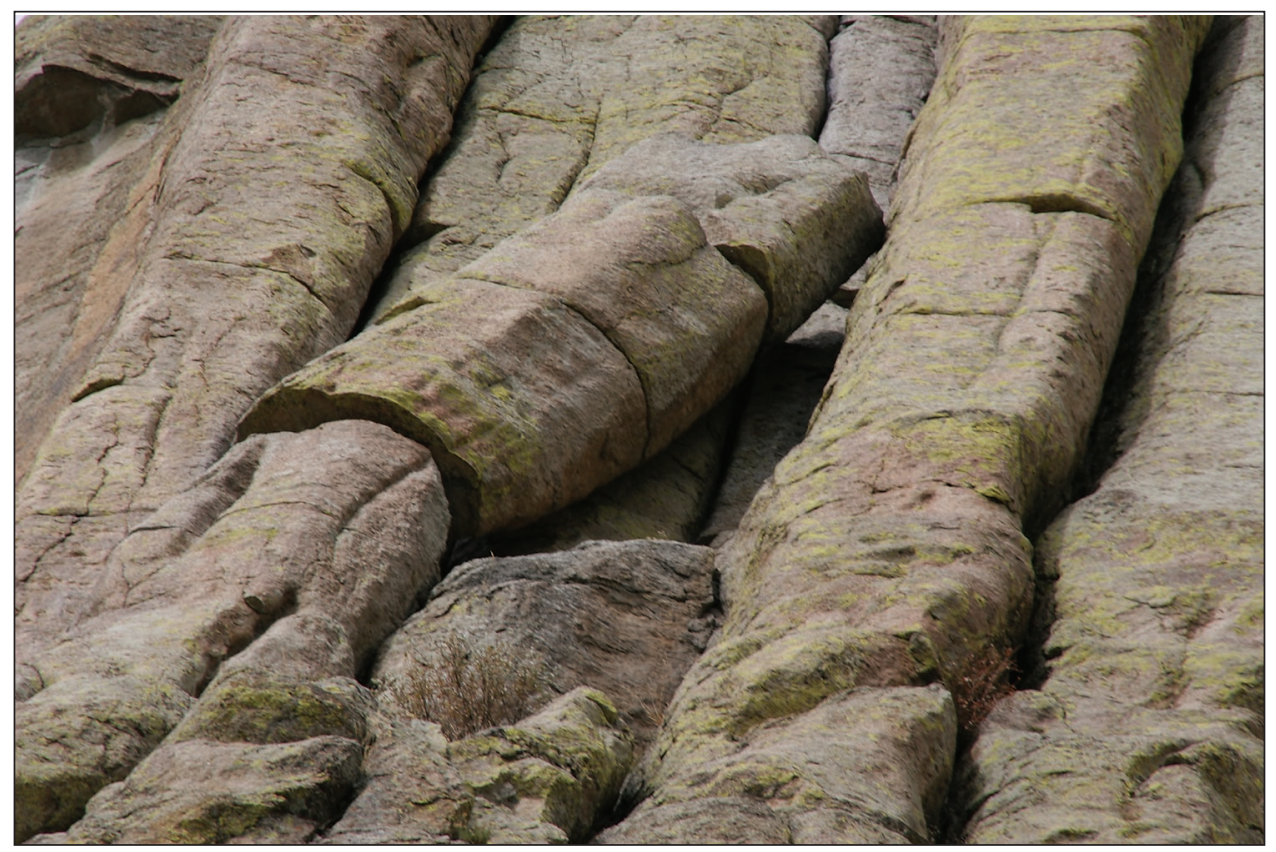

Figure 3. Telephoto of the leaning column showing the three segments, the underlying pedestal, and the upper point contact with an adjacent in-place column. 


\section{CLIMBING HISTORY}

The hundreds of joints that divide Devils Tower into large hexagonal columns attract around 4,000 rock climbers every year. Two local ranchers first climbed the tower in 1893 (Guilmette and others, 2004). Willard Ripley and William Rogers built a wooden ladder to the top of the tower. This ladder provided the only means to the summit and was climbed periodically until the 1920s. Modern rock-climbing techniques were first employed in 1937 by a group of climbers led by Fritz Wiessner. In 1938 Jack Durrance and Harrison Butterworth established the Durrance route, still the easiest and most popular climbing route to the summit of Devils Tower. A prominent feature of this climbing route is the leaning column, a detached column of rock perched on the south face of Devils Tower (figs. 3, 4) about $60 \mathrm{~m}$ above its base.

\section{PRESENT CONDITION OF THE LEANING COLUMN}

In June of 2005, climbers reported that the leaning column was moving in response to the shifting weight of climbers as

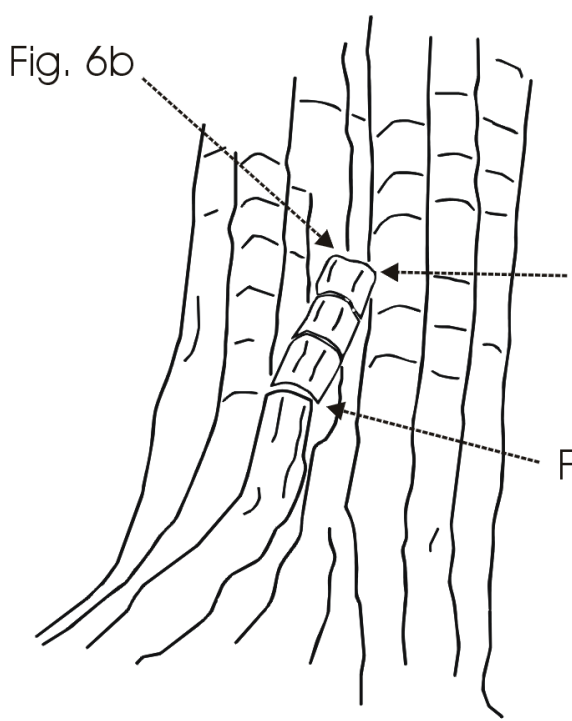

Figure 4. (A) Schematic drawing of leaning column indicating viewing orientations of figures $5,6 \mathrm{~A}$, and $6 \mathrm{~B}$. (B) Leaning column from below with climber standing on top of the column. Line of arrows indicates lower part of Durrance route. they climbed the column or stood on its top. According to NPS personnel and local climbers, the column has been in its present position during historical time and has given no indication of movement until the recent reports in June. In September 2005 two geologists from the U.S. Geological Survey, one a former climbing ranger at Devils Tower National Monument, scaled the column and inspected the column's movement and stability. The motion of the column in response to a person's shifting weight was observed both at its base and at its top. In both cases the motion was initiated by rapidly shifting weight at the top of the column. Once in motion, the column moved with an amplitude on the order of $5 \mathrm{~mm}$ with a frequency of about $2 \mathrm{~Hz}$. The column, which is actually three segments vertically stacked (fig. 4A), moved as a unit.

At its base, the leaning column is in contact with the underlying columnar pedestal along a linear contact (fig. 5). The leaning column is offset from the pedestal to the northeast by approximately $30 \mathrm{~cm}$ where its base rests on the edge of the underlying column, which serves as a fulcrum. The top edge of the leaning column is in point contact with an adjacent column of the tower (fig. 6A, B). Along the linear contact with the underlying pedestal are several hairline fractures extending from the contact downward approximately 10-20 cm (see fig. 5).

Figure 5 shows a patch of relatively fresh phonolite just below the linear contact, suggesting that a flake-shaped piece of the pedestal has recently spalled from the underlying column, possibly in response to the stress concentration imposed by the overlying column along the linear contact.

The overlying 8-m-long column has a mass of approximately $37,000 \mathrm{~kg}$. The leaning column is supported to the northwest by the tower and to the northeast by an adjacent column. The angle between the leaning column and the tower is about $5^{\circ}$, and the angle between the leaning column and the adjacent column to the northeast is about $30^{\circ}$. Making the assumption that the fulcrum

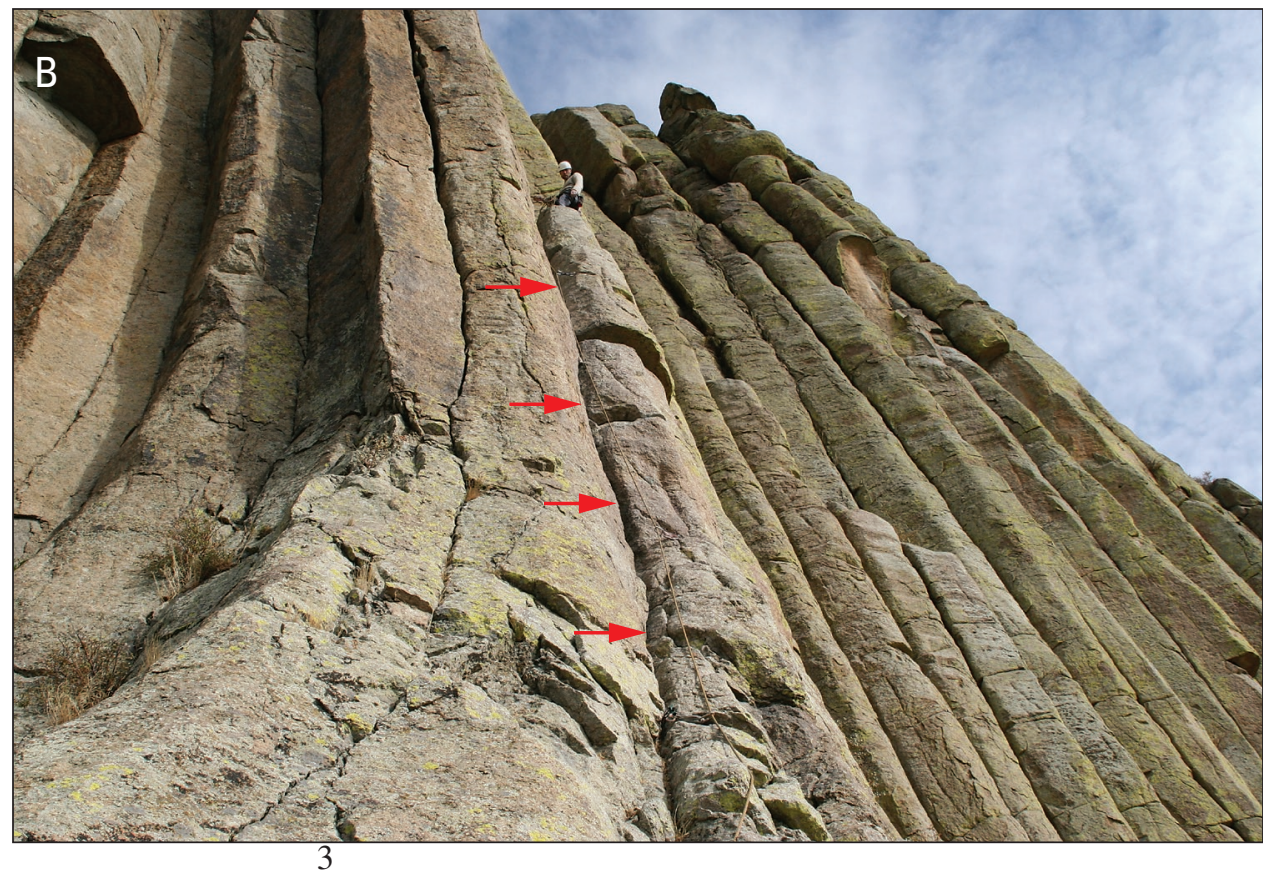




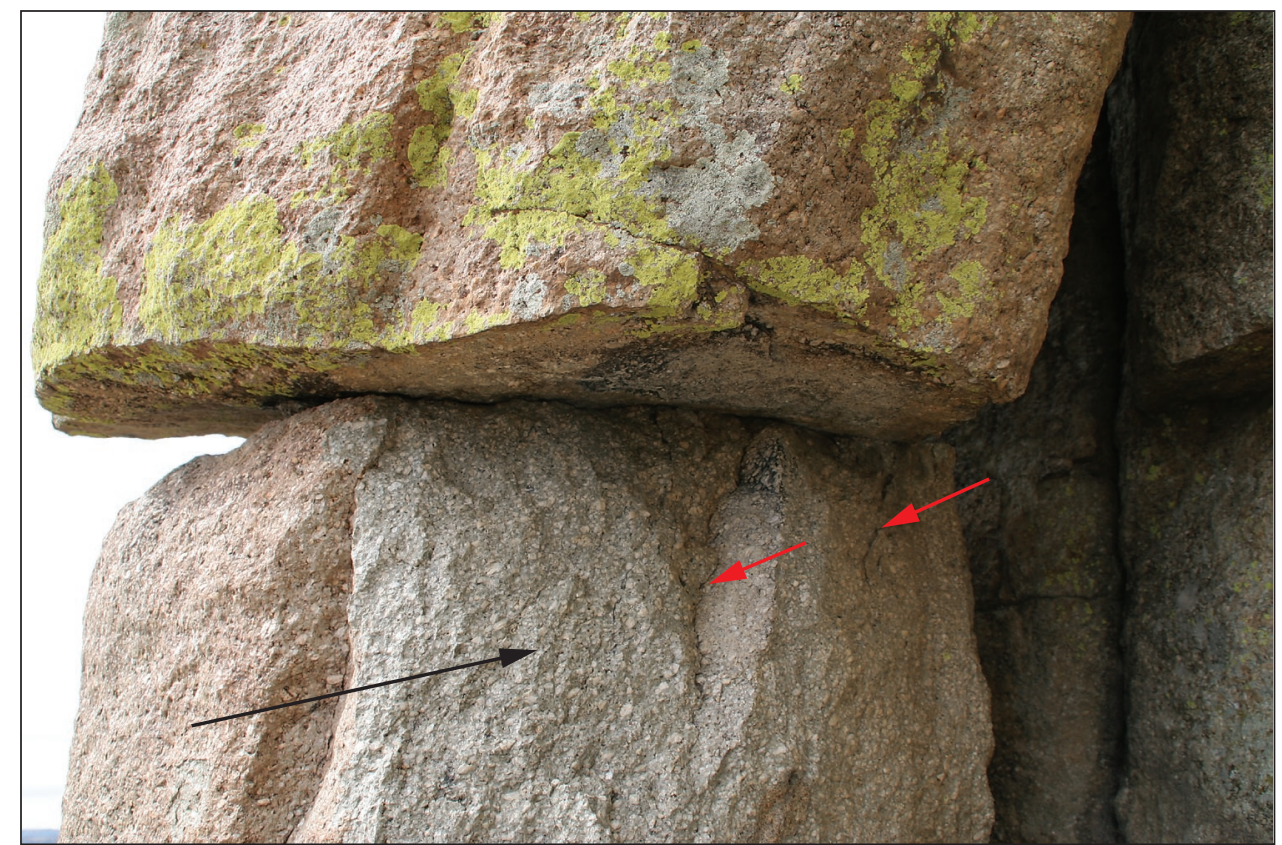

Figure 5. Leaning column resting on underlying pedestal in line contact. Black arrow points to area of fresh phonolite where spalling failure has occurred. Also note hairline fractures (red arrows) extending down from line contact with overlying column. fresh surfaces produced from additional spalling would serve to indicate that the stress concentration is high enough to further fracture the pedestal and that this process might iteratively produce higher stress concentrations until collapse of the pedestal occurred. Additional spalling of the pedestal may also occur when the leaning column is moved by climbers.

\section{CURRENT HAZARD}

At present the hazard to climbers, hikers, and the general public who visit Devils Tower National Monument is unknown. The leaning column may remain in place for years or even hundreds of years. However, if subsequent inspections of the pedestal show additional spalling failure from the painted surface, it is likely that stress fracturing within the pedestal is an ongoing and dynamic process that may destabilize and possibly topple the leaning column. Upon toppling from its present perch, the column will separate is an ideal point instead of a line contact and that the segments would all move as one, the minimum force required to topple the column by pushing on the top of the column opposite the direction of the 5-degree lean is approximately $32 \mathrm{kN}$. However, the motion generated by climbers is more of a rotation about the upper point of contact which, if it actually displaced the column, would tend to swivel it off the underlying pedestal as it rotated about its long axis.

At present, it would seem to require considerably more force than a climber could exert to actually push the leaning column away from the tower and topple it. However, the real concern is that the stress concentration at the linear contact between the leaning column and the pedestal may result in further spalling of the pedestal which could in turn accelerate further fracturing and spalling of the pedestal and lead to eventual collapse of the pedestal and toppling of the leaning column.

\section{MONITORING OF PEDESTAL STABILITY}

The integrity of the pedestal column and the present level of stress concentration placed on it by the overlying leaning column is of paramount importance to the stability of the leaning column. Observation of the pedestal revealed that it is not fractured except in the immediate vicinity of the linear contact with the overlying column (fig. 5). To answer the question of whether the weight of the overlying column may provide sufficient concentration of stress along the linear contact to further fracture the underlying pedestal, we recommended that the area of the pedestal adjacent to the contact be spray-painted (fig. 7) so that any further spalling of the pedestal could be easily detected by observing fresh surfaces upon subsequent inspection. Any into three equidimensional pieces each of about $2.5-\mathrm{m}$ length and $1.5-\mathrm{m}$ diameter (volumes of about $4.5 \mathrm{~m}^{3}$ each). These pieces will accelerate rapidly as they fall and bounce along the steep rock surface of the tower. The boulder field below the leaning column will easily be reached by the three segments traveling at high velocity where collisions with large stationary rocks will occur. Upon impact with massive stationary rocks in the boulder field, shattering of the bouncing rocks and stationary rocks will take numerous directions. Any climbers or hikers in the boulder field at that time will be in extreme danger from the falling, bouncing rocks and fragmentation. Such a scenario occurred on the island of Oahu in May 1999 where basalt boulders of less than $50 \mathrm{~m}^{3}$ fell approximately $146 \mathrm{~m}$ from a nearly vertical slope before hitting other boulders at the base of the cliff near the plunge pool of Sacred Falls. Seven hikers at the plunge pool were killed, and many others were injured (Jibson and Baum, 1999).

\section{MITIGATION OF THE ROCK-FALL HAZARD}

Mitigation of rock-fall hazards falls into three basic categories: (1) prevention, (2) retention, and (3) setback. Prevention techniques consist of removal of the leaning tower segments or securing them (by means of rock bolts or other devices) to adjacent, firmly attached columns of the tower. Due to esthetic considerations and the fact that the area is preserved by the National Park Service as an "unimpaired resource," neither of these options seems to be viable. It would also not be practical place with an attendant shower of high-velocity rock fragments in 
A

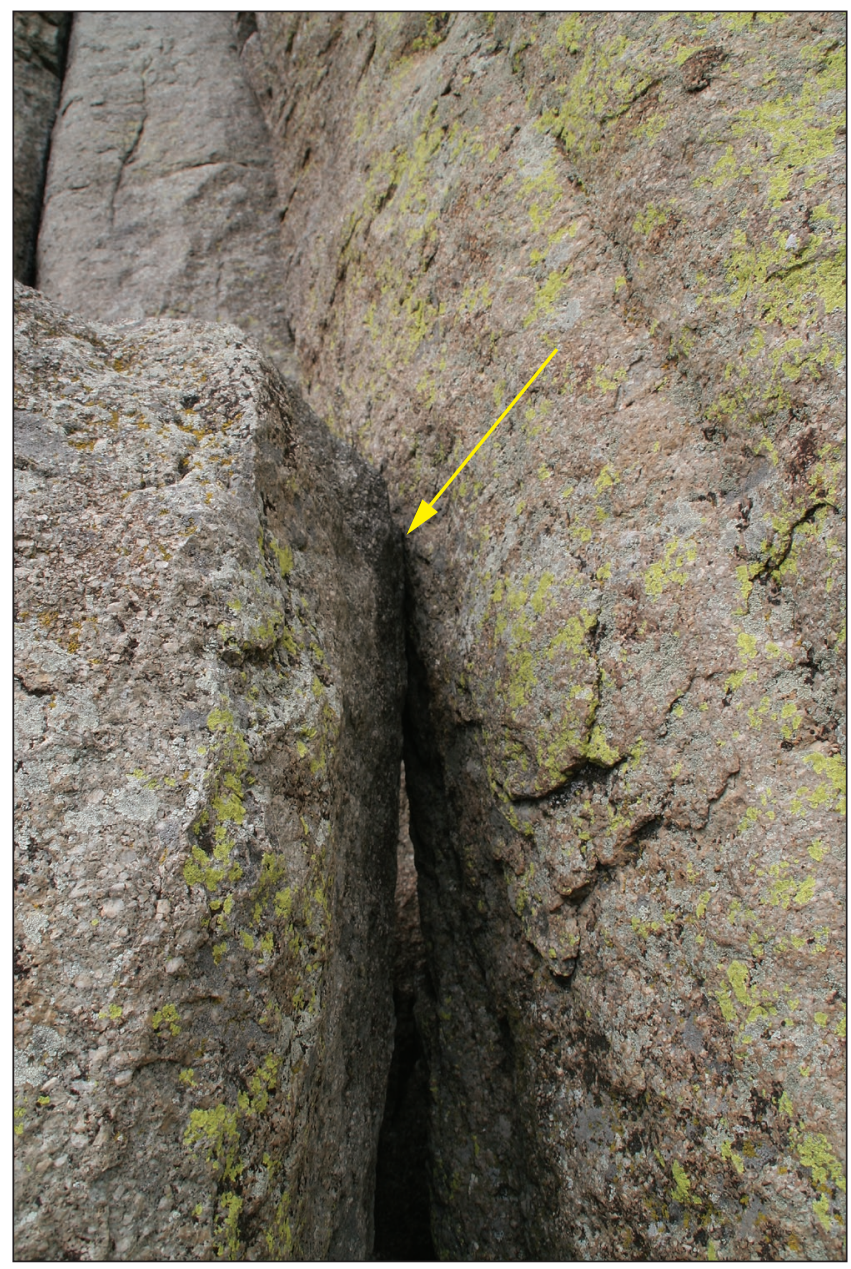

Figure 6. (A) Upper corner of leaning column showing point contact (arrow) with adjacent column, and (B) Point contact of leaning column with adjacent column from above.

\section{B}

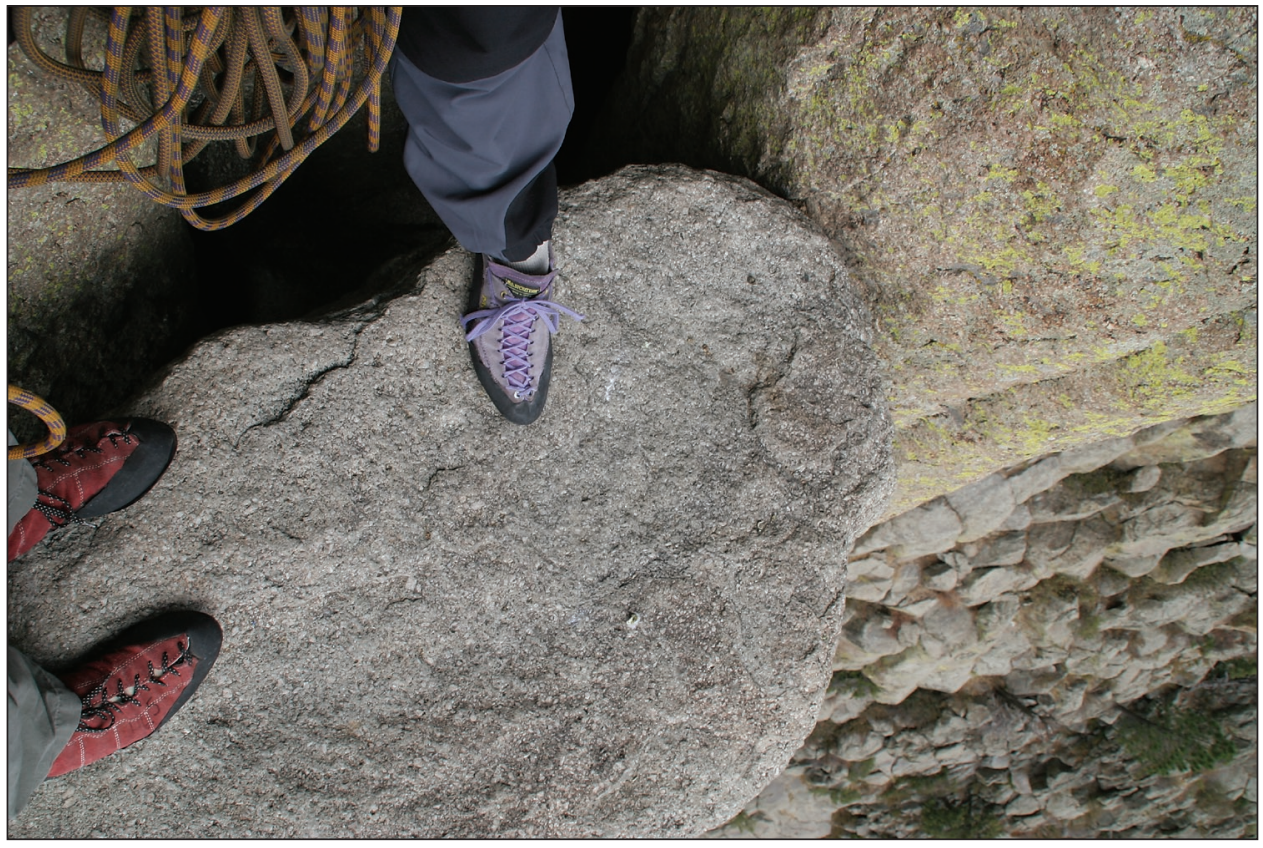




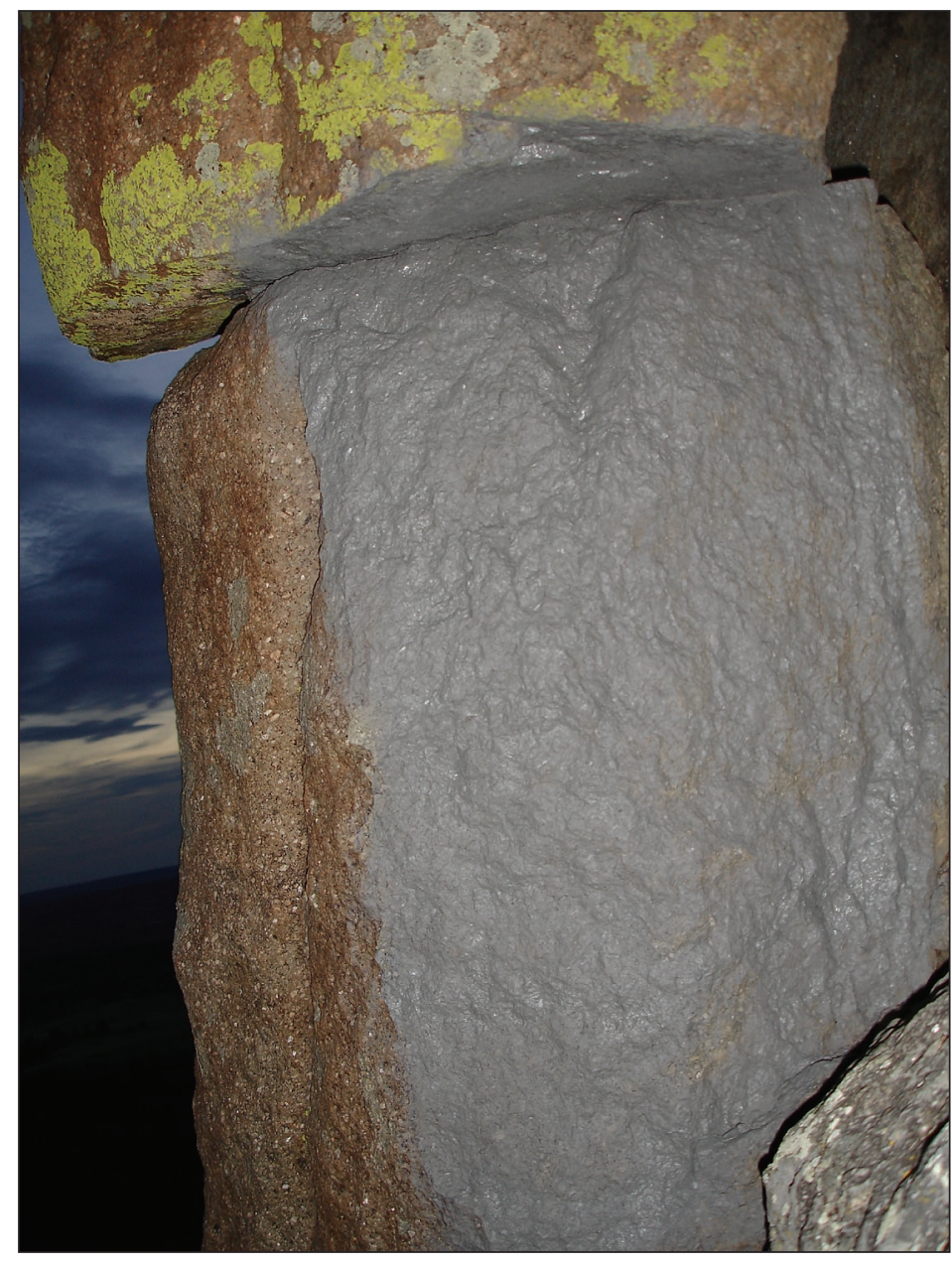

Figure 7. View of line contact of leaning column with underlying pedestal showing freshly painted surface, which will allow any further spalling failures to be detected.

Retention of falling rock by retaining walls located at the base of the tower below the leaning column would also not appear to be viable because any retaining wall would have to be extremely strong to contain boulders of approximately $1-\mathrm{m}$ diameter that have fallen and bounced 60 to $70 \mathrm{~m}$. A retaining wall would have to be quite high to intercept boulders traveling at velocities of up to $120 \mathrm{~km} / \mathrm{hr}$ with attendant large and unpredictable bounces. Such a retaining wall would also be esthetically unacceptable.

The only possible mitigative solution that appears to be viable given the requirement that the area remain unimpaired is that of a setback. Such a setback would take the form of a perimeter of public closure that would keep the public at a safe distance from falling rocks in the event of the collapse of the leaning column. The brief reconnaissance that we made of the area below the leaning column suggests that such a perimeter could be based on the distribution of the talus below the leaning column.

Directly below and to the southeast of the leaning column is a boulder field of talus that has come from the same section of the tower as the leaning column. The talus distribution extends to the southeast from the tower for approximately $300 \mathrm{~m}$ to the edge of a topographic bench that is roughly $130 \mathrm{~m}$ above the flood plain of the Belle Fourche River where the NPS Visitor's Center and administration buildings are located. The distribution of the talus to the upper (southern) edge of the bench probably defines the farthest distance that the segments of the leaning column could possibly travel. Most likely the segments or their fragments would be arrested short of this limit due to collisions with the boulders within this talus field. The 300-m distance limit (rockfall hazard zone) in this direction is therefore a conservative estimate of possible travel.

\section{PROPOSED METHOD OF HAZARD MAPPING}

To map the hazard from a toppling failure of the leaning column, a perimeter setback should be established based on precise mapping of the limits of the talus field extending away from the leaning column area of the tower to the southeast. Existing aerial photography of the tower and ground-based fieldwork should be employed to provide an accurate map of the talus distribution and limit in this direction. Such a map could then provide the basis for establishing a setback or perimeter of closure to the public should future inspections of the pedestal indicate that pieces are continuing to spall from it, indicating that it is not stable but in a condition of ongoing failure (rate unknown) due to the stress concentration of the overlying column.

\section{SUMMARY AND RECOMMENDATIONS}

In response to reports from rock climbers at Devils Tower National Monument that the leaning column on the popular Durrance route to the summit was moving when subjected to climbers' weight and movements, geologists from the U.S. Geological Survey visited the site and inspected the column and the underlying base supporting it to determine the present condition and stability of the column and basal pedestal. The inspection confirmed the reports of column motion and established that a relatively fresh rock surface and recent fractures were present in the underlying pedestal adjacent to its contact with the overlying column. Our observations during this inspection led us to the following conclusions and recommendations.

- The leaning column does move with the weight and movement of climbers with vibrations of about $5-\mathrm{mm}$ amplitude at roughly a frequency of $2 \mathrm{~Hz}$.

- The pedestal underlying the column has a relatively fresh surface of phonolite adjacent to the linear contact between the column and the pedestal that was probably created by spalling of a fragment of the pedestal due to the stress concentration imposed by the weight of the overlying column along the contact.

- Fractures present in the underlying pedestal near its contact with the leaning column seem to be recent and were probably created when a recent spalling failure occurred. 
- The area around the contact between the column and pedestal should be spray-painted so that any new spalling failures can be detected and documented.

- Any new failures detected would indicate that the condition of the contact between the column and the pedestal is unstable and that closure of the route to climbers should be considered.

- New failures would also indicate that the area below the leaning column could be hazardous from a possible toppling failure of the column and subsequent rock fall.

- Determination of the area of possible rock-fall travel below the leaning column should be made by mapping the distribution of talus accumulation in that area of the monument.

- The area of talus accumulation below the leaning column would be hazardous in the event of column failure and should be considered for closure to the public.

\section{ACKNOWLEDGMENTS}

National Park Service personnel (Lisa Eckert—Superintendent, Scott Brown-Chief Ranger, and Jim Cheatham-Chief Resource Management Officer) provided logistical support for the investigation of the leaning column. Access to climbing, safety, and communication equipment was granted to facilitate the inspection of the column and the surrounding area to assess the hazard to monument visitors and Park Service personnel.

\section{REFERENCES}

Darton, N.H., and O'Harra, C.C., 1907, Devils Tower [quadrangle], Wyoming-South Dakota-Montana: U.S. Geological Survey Atlas of the United States, Folio 128, 8 p.

Duke, G.I., Singer, B.S., and Dewitt, E., 2002, ${ }^{40} \mathrm{Ar} /{ }^{39} \mathrm{Ar}$ laser incremental-heating ages of Devils Tower and PaleoceneEocene intrusions of the northern Black Hills, South Dakota and Wyoming: Geological Society of America Abstracts with Programs, v. 34, no. 6, p. 473.

Guilmette, R., Carrier, R., Gardiner, S., and Lindsay, C., 2004, Devils Tower National Monument Climbing HandbookDevils Tower, WY: Devils Tower Natural History Association, $176 \mathrm{p}$.

Halvorsen, D.L., 1980, Geology and petrology of the Devil's Tower, Missouri Buttes, and Barlow Canyon area, Crook County, Wyoming: Grand Forks, University of North Dakota, Ph.D. thesis, 218 p.

Jagger, T.A., Jr., 1901, Laccoliths of the Black Hills: U.S. Geological Survey Annual Report 21, pt. 3, p. 163-290.

Jibson, R.W., and Baum, R.L., 1999, Assessment of landslide hazards in Kaluanui and Maakua Gulches, Oahu, Hawaii, following the 9 May 1999 Sacred Falls landslide: U.S. Geological Survey Open-File Report 99-364, 9 p.

Newton, H.A., and Jenney, W.P., 1880, Report on the geology and resources of the Black Hills of Dakota: U.S. Geographical and Geological Survey of the Rocky Mountain Region, $222 \mathrm{p}$.

Small, E.E., and Anderson, R.S., 1998, Pleistocene relief production in Laramide mountain ranges, western United States: Geology, v. 26, no. 2, p. 123-126.

Zaprowski, B.J., Evenson, E.B., Pazzagalia, F.J., and Epstein, J.B., 2001, Knickzone propagation in the Black Hills and northern High Plains-A different perspective on the late Cenozoic exhumation of the Laramide Rocky Mountains: Geology, v. 29, no. 6, p. 547-550. 